The Engine Laboratory (88 ft. $\times 30 \mathrm{ft}$.) has eight. fully equipped engine test bays. The walls, ceilings and partitions of the Laboratory are treated with sound-absorbing material; and the walls are not directly connected with the rest of the building, so as to reduce transmission of noise and vibration. Engine stands and dynamometers are mounted together on large concrete beds which are cushioned on rubber to reduce vibration transmitted to the floor. Three beds have electric dynamometers and the other five water brakes. Fuel lines (diesel and petrol) run to each bed, together with water and electric power. As well as investigations concerning the operation of the power-unit as such, any work involving the running of an engine under power is carried out in this Laboratory; for example, the measurement of loads in crankshafts (in progress at the time of writing) using wire-resistance straingauges attached to the shaft.

The workshop, which is fully equipped to undertake all the Association's needs for special apparatus, instruments and test specimens, is $100 \mathrm{ft} . \times 29 \mathrm{ft}$.; and there is a general stores of similar size. There is a small drawing office $(50 \mathrm{ft} . \times 20 \mathrm{ft}$.) and photographic rooms $(40 \mathrm{ft}$. $\times 22 \mathrm{ft}$. $)$. The conference room, which is equipped for the projection of $35-\mathrm{mm}$. sound films and lantern slides from a projection room outside it, is $46 \mathrm{ft} . \times 22 \mathrm{ft}$. In addition to the library (40 ft. $\times 22 \mathrm{ft}$.), in which only bound volumes are kept, there is a library store $(46 \mathrm{ft} . \times 22 \mathrm{ft}$.) for unbound literature. Through the Information Section about 7,000 loans of technical literature are made each year, and for documents in great demand a photo-copying service is operated.

Obviously, much of the Association's research. work, such as that connected with stresses in vehicle structures and noise in vehicles, has to be carried out on the road, and the Proving Ground provides private roads for this purpose. In addition, the Proving Ground has been equipped with features which make it a testing ground on which manufacturers can prove their vehicles, as well as using it for development and research work which would otherwise (and less conveniently) have to be carried out on public roads. The Proving Ground covers nearly 650 acres, with $12 \frac{1}{2}$ miles of track and special road surfaces ; features include a banked circuit on which high speeds can be continuously maintained; a pavé track which is used for accelerated endurance tests on complete vehicles; a corrugated track which reproduces the well-known non-metalled 'washboard' roads of tropical and sub-tropical countries; a "water splash'; a 'dust tunnel' for studying dust entry, etc.

\section{NEW BUILDINGS FOR THE UNIVERSITY OF GLASGOW}

$\mathrm{T}$ a ceremony held in the Bute Hall of the
University of Glasgow on March 19, the Right
Hon. James Stuart, Secretary of State for Scotland,
inaugurated the new buildings which have been
erected for the University since the conclusion of the
Second World War. Some of these buildings are not
yet complete, but they are all in use. There are six
entirely new buildings, ranging from the final block
of the new Chemistry Institute, with a floor area of
more. than 80,000 sq. ft. and costing more than
$£ 500,000$, to a small extension of the Zoology Depart- ment, with a floor area of some 5,600 sq. ft. and built at a cost of $£ 24,500$. In addition, there have been major works of reconstruction and adaptation which have provided increased accommodation and more modern facilities for the University Offices and for the Departments of Bacteriology, Biochemistry, Botany, Genetics, Mathematics and Pharmacology. Also, a factory has been purchased and is being converted into a research block for mechanical engineering. In all, these new buildings and reconstructions have cost about $£ 2$ million, of which more than 90 per cent has been provided from public funds.

The most mundane of these projects is the new boiler-house (architects : Messrs. Gillespie, Kidd and Coia). This had become necessary not only because the old boilers were on the verge of complete breakdown, but also because they were quite unable to meet the demands of the new buildings in course of construction on Gilmorehill. Construction of the new boiler-house involved a difficult and costly excavation of the hillside. The northern side of the roof is on a level with the adjoining roadway and on the roof itself are two excellent tennis courts. Three Penman's economic boilers have been installed, each of which can give 12,500 lb. of steam per hour. The fuel store takes 560 tons of coal, which is fed to the stoker hoppers by coal elevators. The only man-handling needed is in raking out the ash, and the efficient operation of the plant is assisted by the usual automatic recorders. Considerable economy in fuel has resulted from this installation.

The new extension for the Department of Natural Philosophy (architects: Messrs. Basil Spence and Partners) is more advanced in its architectural conception than any other of the University buildings. It provides increased and modern facilities for research in both experimental and theoretical physics. The rectangular main block, consisting of four floors and a basement, each with a central corridor, has at the east end a $300-\mathrm{MeV}$. synchrotron with its associated rooms. In the main block are about twenty research rooms, mainly used for small-scale researches in nuclear physics. The unit size is $16 \mathrm{ft}$. by $16 \mathrm{ft}$., but a few rooms consist of one and a half such units and a few of two units. Techniques rooms, photographic dark-rooms, rooms for mathematical physicists, private rooms, a museum and a library complete the main block.

The synchrotron end of the building consists of a main hall, $54 \mathrm{ft}$. by $26 \mathrm{ft}$., for general machineassembly purposes, this hall containing a 50-ton crane with which the whole of the top section of the synchrotron magnet can be lifted. A large part of the floor of this hall consists of a sliding slab of barytes concrete $2 \mathrm{ft}$. thick and weighing 120 tons which, when closed, forms the roof of the chamber in which the synchrotron magnet is housed below ground-level. The rest of the building is thus screened effectively from the radiation and noise of the synchrotron. The beam of high-energy radiation passes through a door in the synchrotron chamber into a beam room, $33 \mathrm{ft}$. by $16 \mathrm{ft}$., also below groundlevel. Immediately above this are two research rooms with slots in the floor, so that the apparatus in the beam room may be watched and manipulated from a safely screened position.

The main synchrotron magnet weighs 120 tons, of which 70 tons is constructed of laminations $0.014 \mathrm{in}$. in thickness. The diameter of the circular orbit of the electrons during acceleration is $2 \frac{1}{2} \mathrm{~m}$. The magnet is excited five times a second with a 
peak current of 3,300 amp. obtained by the discharge of the condenser block, the total capacity of which is $3,220 \mu \mathrm{F}$., the condensers being charged to $8.5 \mathrm{kV}$. The large rectifier housed in a separate room generates $26 \mathrm{kV}$., from which a stable voltage supply of $17 \mathrm{kV}$. is provided for charging condensers. The energy of the accelerated electrons is $300 \mathrm{MeV}$. at full operation; but at this figure the magnetic field is only 8,000 gauss, and it is expected that the voltage will ultimately be increased to give an energy of more than $400 \mathrm{MeV}$.

The small extension to the Department of Zoology (architects: Messrs. John Keppie and Henderson and J. L. Gleave) was the first of the new buildings to be completed and has been in use for some years, primarily for teaching and research in the applied branches of the subject. In a teaching laboratory which accommodates some fifty students, practical instruction is provided in agricultural zoology and zoology for veterinary students, as well as in entomology for advanced students. There are staff rooms, research rooms, balance room, a small preparation room, a hot room for insect cultures, and an extension to the departmental library.

The new wing for the Chemistry Department completes a building scheme begun in 1937 (architects : Messrs. T. Harold Hughes and D. S. R. Waugh) and interrupted by the outbreak of the War. The two blocks built then now house the organic chemistry and part of the physical chemistry sections of the Department, with laboratories for medical and dental students; they have also three lecture theatres of varying sizes, a library and a large central store. All three blocks are constructed of ferroconcrete faced with buff-coloured brick, which contrasts with the stone facing of all other University buildings in the vicinity.

The new post-war block contains the inorganic chemistry section of the Department, a large lecture theatre, the sub-department of agricultural chemistry, and two large laboratories for first-year students (science, engineering and veterinary medicine). One of these, a ground-floor laboratory well lit from a glass roof, is flanked on three sides by the remainder of the building, which rises to a height of two more stories. There are also many research rooms, principally for physical chemistry, with a number of special-purpose rooms; for example, for electrochemistry, polarography, microchemistry, etc. A well-appointed conference room and a museum are also included. A number of the larger laboratories are fitted with ventilation units by which warmed. and filtered air replaces that lost through the fume cupboards and extraction ducts. Hydrogen sulphide generated in a large apparatus on the roof is led through polythene tubing to the points where it is required in the principal teaching laboratories. The more costly items of equipment recently installed in the Department include a Metropolitan-Vickers mass. spectrometer, a Phillips electron microscope, and a Perkin-Elmer recording infra-red spectrophotometer. The three blocks of the complete building, interconnected by corridors on each of the three levels, make up an impressive Department of Chemistry, probably more extensive than that in any other British university.

The new building for the Department of Surgery (architects: Messrs. T. Harold Hughes and D. S. R. Waugh) is of more modest dimensions. It is a fivestory building in Church Street, flanked on one side by the (xardiner Institute of Medicine and on the other by the Tennent Institute of Ophthalmology. A short corridor gives direct access to the surgical wards of the Western Infirmary, where much of the teaching of the Department is carried out. Classes are held in the conference room on the top floor, which is also available for the use of other University departments on the hospital site. The third floor has a museum, a laboratory for clinical investigations and a staff common-room. Below this are more laboratories, for research of biochemical and physiological types. The first floor makes provision for histology, photographic work and medical illustration. On the ground floor is a library, and in the basement an X-ray department and a room for work with radioactive isotopes. Some of the work in progress in the Department is concerned with the study of peptic ulcer, and includes investigations on the epidemiology of ulcer, the physiology of gastric secretion and motility, and the effect of drugs on the stomach.

The Veterinary Hospital (architects: Messrs. Gillespie, Kidd and Coia) is the least advanced of the six new buildings, although part is already in use. It rises on the bank of the River Kelvin in the attractive Garscube estate, about three miles from the main University site. The primary purpose of the Hospital is to provide clinical material for teaching students in the University Veterinary School; much investigation is being carried out also, especially into aspects of livestock managementi bearing on diseases which constitute an economic problem.

The Hospital comprises buildings for all kinds of domestic animals, and includes the laboratories, operating rooms, X-ray rooms, library and student amenity rooms which make up a modern hospital. The large- and small-animal wings, now in use, run from east to west, parallel to each other, and enclose a yard which is divided into small pens suitable for exercising and retaining animals. The yard is closed on its third side by an east-west block, still under construction, which projects north and south of both the animal wings. As the site slopes from south to north, this north-south wing is a single-story building on the south side, and becomes three-storied on the north side. The main building is a steel-frame building, and an attractive hard-clay brick is being used for the outer fabric.

The entire unit provides accommodation for most types of animals, with facilities for teaching students and carrying out laboratory investigations. There are two lecture theatres, laboratories for biochemistry and physiology, photographic rooms, a clinical pathology laboratory, post-mortem rooms, etc. There is a Large Animal Operating Theatre. This will be used mainly for horses and cattle, and is furnished with a hydraulic operating table capable of taking a horse from the vertical position to the horizontal and of being stabilized at any convenient level for the operator. X-ray equipment will be used both in this operating theatre and in the small-animal operating theatre. X-ray examination of large animals presents peculiar problems, and the designing of a Buckie screen in the floor capable of supporting an animal which may weigh a ton has presented considerable difficulty. Since the former Glasgow Veterinary College was taken over by the University some five or six years ago, its premises have been greatly modified and improved, and the Veterinary School is now provided with good accommodation and equipment. The completion of the new Veterinary Hospital 
will mark a further stage in the development in Glasgow of first-class facilities for the training of veterinary practitioners.

Indeed, the new buildings which were inaugurated. on March 19 represent for the University as a whole merely a stage of development rather than the fruition of its plans. Much still remains to be done. The temporary buildings for the Department of Chemistry which were in use for half a century are now being demolished, and soon the site will be clear for an extension of the engineering departments.

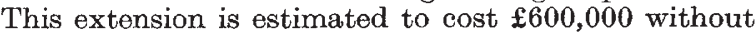
equipment and, of this, industry has contributed $£ 220,000$. A new building has been planned for some of the arts departments, and it is hoped that a start, will be made within a very few years. In their turn will come also student residences (only one University has a smaller proportion of its students in halls of residence than has Glasgow), a new University Library and a larger provision for some of the medical and biological departments. When this second stage is complete, the worst of the post-war shortages of accommodation will have been remedied. What the third stage will comprise must be left for future decision. Those who will be responsible for deciding will be greatly helped by the master-plan of University development drawn up a fow years ago by the late Sir Frank Mears.

\section{OBITUARIES}

\section{Prof. A. B. Dobrowolski}

Antoni B. Dobrowolski, Polish meteorologist and hydrologist, whose death has been recently announced, was born in 1872. Like most of his scientifically minded countrymen of that period, he had to turn to the West for his education-in his case to Zurich and Liège. In 1897 Belgium was entering the field of Antarctic exploration, and Henryk Arctowski and Dobrowolski joined the scientific staff of the Belgica expedition under the leadership of A. de Gerlache de Gomery with Roald Amundsen as first mate. The ship got stuck in the ice in the west of the Bellinghausen Sea near lat. $70 \frac{1}{2}^{\circ} \mathrm{S}$., long. $86^{\circ} \mathrm{W}$. at the beginning of the southern winter of 1898. It had perforce to spend the winter there, and so the expedition became the first to take regular meteorological observations and maintain continuous autographic records of pressure and temperature in one part of the Antarctic over a complete year, though not without much hardship and suffering.

Dobrowolski concentrated on the observations of the forms and motions of clouds and on the observation and description of the different forms of snow and ice in the atmosphere. In his treatment of the former he broke new ground in his description of the 'cloud system' and his emphasis on its importance in meteorology. A 'cloud system' covers a large area, and the form of cloud in any part of the system depends on its relative position. Some twenty years after the publication of Dobrowolski's memoir, the significance of these cloud systems, largely owing to their study by French meteorologists, had a profound influence on the work of the International Commission for Synoptic Meteorology and afterwards on the international classification of clouds. Dobrowolski's observations of the motion of clouds were utilized by Simpson in his construction of the pressure distribution at $a$ height of $3,000 \mathrm{~m}$. over the Antarctic ; the Belgica, the Gauss, the South Orkneys and Erebus provided a ring of nearly equally spaced observations near lat. $70^{\circ} \mathrm{S}$.

F. M. Exner paid a warm tribute to the care and accuracy of Dobrowolski's descriptions of the observed forms of snow and ice crystals when he used them in his revision of the theory of halo phenomena in Pernter-Exner's "Meteorological Optics". Dobrowolski himself maintained that the crystals effective in producing halos were probably the holohedric hexagonal 'columns' and the hemimorphic prisms with an attached plate, because these would tend to float with their axes in one direction, and that simple plates and needles could be practically excluded from consideration as halo formers.

Ice in its manifold forms became, indeed, Dobrowolski's main subject. He wrote a comprehensive treatise, "The Natural History of Ice", published in 1923 under the auspices of the Polish Institute for the Advancement of Science. It was an encyclopædic work of international repute and should have been, as its author desired, in an international language'. But it had to be in Polish because the pre-1914 founders of the Institute, desirous of banning the Russian language, had made a rule forbidding all languages other than Polish as the only way, then permissible, of securing their object.

Dobrowolski was director of the Polish National Meteorological Institute during 1924-29. Thereafter, conscious of the dependence of hydrology on meteorology, he sought support at international meetings for his thesis that the meteorological and hydrological services in each country should be united under one head, to secure the close collaboration of which the need was self-evident. $\mathrm{He}_{\Theta}$ also pressed for the formation of an Association of Cryology in the International Union of Geodesy and Geophysics to replace the Snow and Ice Commission of the Hydrology Association. E. GoLD

\section{Colonel L. J. Hudleston}

Lawson John Hudleston, who died on April 25, was born on May 8, 1891, and was educated at University College School, and University College, London, where he graduated in 1913. His postgraduate research was soon interrupted by the First World War ; holding a Special Reserve Commission, he served with the lst Middlesex Regiment through the retreat from Mons, was mentioned in dispatches and awarded the Military Cross in 1915. He was transferred to the Ministry of Munitions in 1917 and worked on the synthesis of ammonia until the end of the War; then, as Salters Fellow, he was with Prof. H. Bassett at Reading for a year.

In January 1920 he was appointed lecturer at the University College of Wales, and he settled down in Aberystwyth, marrying Miss Mabyn Thompson, of the Zoology Department, who, with one daughter, survives him; he had been senior lecturer in the Chemistry Department for many years at the time of his death. Persuaded to take command of the Aberystwyth T.A. Battery in 1936, he was in command of the Cardiganshire Field Regiment, R.A., in 1939, and again served throughout the War, during the latter half of it on the staff of the Scientific Adviser to the Army Council. Here his flair and enthusiasm for applying scientific method to novel problems was of great value, and he did important 